\title{
Proses Perencanaan Tahunan Dinas Kesehatan Kabupaten Padang Pariaman
}

\author{
The Annual Planning Process in Dinas Kesehatan Kabupaten Padang \\ Pariaman
}

\section{Jasrida Yunita}

\section{Program Studi Magister Ilmu Kesehatan Masyarakat STIKes Hang Tuah Pekanbaru}

\begin{abstract}
ABSTRAK
Di Dinas Kesehatan Kabupaten Padang Pariaman terjadi kecenderungan penurunan capaian indikator program kesehatan dalam dua tahun terakhir. Salah satunya disebabkan oleh kurang sempurnanya perencanaan program dan kegiatan yang direncanakan setiap tahunnya. Ini bisa saja terjadi karena dalam proses penyusunan perencanaan tersebut tidak mengikuti alur perencanaan, konsultasi, bimbingan teknis maupun koordinasi. Tujuan penelitian diketahuinya proses penyusunan perencanaan Dinas Kesehatan Kabupaten Padang Pariaman. Metode penelitian menggunakan pendekatan kualitatif dengan teknik wawancara mendalam dengan 17 orang informan. Hasil penelitian menyatakan alur perencanaan belum sesuai dengan langkah perencaaan terpadu, konsultasi belum maksimal, bimbingan teknis langsung ke Bappeda dan koordinasi juga masih belum optimal. Agar perencanaan berkualitas, maka perlu pedoman dalam penyusunan perencanaan, konsultasi perlu dimonitoring pimpinan, bimbingan teknis disosialisasikan dan rapat koordinasi tiap akhir tahun dengan lintas sektor.
\end{abstract}

Kata kunci: Alur Perencanaan, Konsultasi, Bimbingan Teknis, Koordinasi, Dinas Kesehatan Kabupaten Padang Pariaman

\begin{abstract}
Dinas Kesehatan Padang Pariaman occured trends decreasing indicators achievement of health programs in the last two years. This is one of them caused by defective planning programs and activities that are planned each year. This caused by the planning was not following the path planning, consulting, technical guidance and coordination. The purpose of this research will know the annual planning process in Dinas Kesehatan Kabupaten Padang Pariaman. The research method uses a qualitative approach with using the technique of personal interviews with 17 informants. The results explain the chronology of the path planning has not followed the steps according to the rules, monitoring of supervisors on the implementation of consultation is still lacking, the technical guidance of accomplished and implementation coordination is still less than optimal. In order for planning has quality, it is necessary to gives guidance of planning, monitoring on the implementation of consultation, socialization of the technical guidance and the meet of coordinating every end of the year with correlated sectors.
\end{abstract}

Key words: planning path, consulting, technical guidance and coordination Dinas Kesehatan Kabupaten Padang Pariaman

\section{PENDAHULUAN}

Perencanaan kesehatan adalah sebuah proses untuk merumuskan masalah-masalah kesehatan yang berkembang di masyarakat, menentukan kebutuhan dan sumber daya yang tersedia, menetapkan tujuan program yang paling pokok dan menyusun langkahlangkah praktis untuk mencapai tujuan yang telah ditetapkan (Muninjaya, 2004).

Keberhasilan program salah satunya ditentukan oleh perencanaan yang baik, namun masih ada permasalahan yang dihadapi dalam penyusunan perencanaan kesehatan ini. Bakri (2001) menyatakan bahwa permasalahan yang dihadapi dalam perencanaan kesehatan adalah belum adanya Tim Khusus yang mengelola manajemen perencanaan kesehatan kabupaten/kota; masih lemahnya kemampuan petugas kesehatan dalam berbagai aspek proses perencanaan; masih kurang dilibatkannya masyarakat dan sektor terkait dalam proses perencanaan kesehatan dan belum digunakannya model/siklus perencanaan tertentu dalam proses perencanaan.

Selama tiga dekade terakhir ini, hasil dari perencanaan kesehatan telah berhasil meningkatkan pelayanan kesehatan dasar secara lebih merata sehingga dapat menurunkan angka kematian bayi dan balita, meningkatkan kesehatan ibu dan anak, meningkatkan keadaan gizi masyarakat dan memperpanjang harapan hidup rata-rata penduduk. Namun dalam beberapa tahun terakhir, pembangunan kesehatan menghadapi tantangan yang cukup besar dalam mempertahankan peningkatan status kesehatan masyarakat. Indikasi ini terlihat dari melambatnya penurunan kematian ibu, kematian bayi dan meningkatnya kekurangan gizi pada balita (Bappenas, 2009). 
Kabupaten Padang Pariaman yang merupakan salah satu kabupaten yang ada di Propinsi Sumatera Barat, juga berupaya dalam menurunkan angka kematian terutama AKI dan AKB. Ini terbukti dengan adanya program upaya kesehatan masyarakat dalam menurunkan AKI dan AKB ini dalam RPJMD Kabupaten Padang Pariaman tahun 2006-2010 yang merupakan program dari Dinas Kesehatan Kabupaten Padang Pariaman.

Dinas Kesehatan Kabupaten Padang Pariaman sudah berupaya dalam meningkatkan status kesehatan masyarakat termasuk dalam penurunan AKI dan AKB. Apabila dilihat dari pencapaian indikator kinerja kunci (IKK) yang terdapat dalam standar pelayanan minimal (SPM) Dinas Kesehatan Kabupaten Padang Pariaman dalam dua tahun terakhir ini, masih ada beberapa indikator yang belum mencapai target dan mengalami penurunan yang disebabkan kurang sempurnanya perencanaan program dan kegiatan yang dibuat setiap tahunnya. Diantaranya ibu hamil resti dirujuk (target $100 \%$ mengalami penurunan dari $85 \%$ pada tahun 2008 menjadi $13,33 \%$ pada tahun 2009; Neonatal resti dan komplikasi ditangani (target 80\%) mengalami penurunan dari $84,07 \%$ tahun 2008 menjadi $46 \%$ pada tahun 2009; pertolongan persalinan oleh bidan/tenaga ahli (target 90\%) mengalami penurunan dari $82,9 \%$ pada tahun 2008 menjadi 79,1\% pada tahun 2009; 98\% Universal Child Immunization (UCI) sampai akhir tahun 2009 juga belum tercapai tetapi mengalami peningkatan dari $85 \%$ pada tahun 2008 menjadi $87 \%$ pada tahun 2009; dan cakupan kunjungan bayi (target $90 \%)$ juga mengalami penurunan dari $99,6 \%$ pada tahun 2008 menjadi $80 \%$ pada tahun 2009 (Padang Pariaman, 2010).

Untuk mencapai target indikator tersebut perlu sebuah dokumen perencanaan yang baik sebagai acuan dalam pelaksanaan kegiatan. Untuk menghasilkan dokumen perencanaan yang baik maka selain didukung oleh sumber daya yang memadai juga diharapkan dalam proses penyusunannya juga baik, seperti mengikuti alur perencanaan, melakukan konsultasi dengan pihak-pihak yang berhubungan dengan penyusunan perencanaan, perlunya bimbingan teknis serta koordinasi baik dengan lintas program maupun lintas sektor.

Dari wawancara yang dilakukan dengan beberapa pegawai Dinas Kesehatan Kabupaten Padang Pariaman menyatakan bahwa belum pernah dilakukan penelitian tentang proses penyusunan perencanaan, sehingga belum diketahui betul bagaimana alur perencanaan, konsultasi, bimbingan teknis serta koordinasi yang telah dilakukan. Maka dari itu penulis tertarik melakukan penelitian tentang proses penyusunan perencanaan Dinas Kesehatan Kabupaten Padang Pariaman. Tujuan dari penelitian ini adalah diketahui proses penyusunan perencanaan di Dinas Kesehatan Kabupaten Padang Pariaman.

\section{METODE}

Metode penelitian menggunakan pendekatan kualitatif yang dilaksanakan di Dinas Kesehatan Kabupaten Padang Pariaman tahun 2010 dengan menggunakan teknik wawancara mendalam dengan 17 orang informan yang terlibat dalam penyusunan perencanaan di Dinas Kesehatan Kabupaten Padang Pariaman. Instrumen penelitian menggunakan pedoman wawancara mendalam, alat pencatat dan alat perekam. Teknik pengumpulan data dengan metode wawancara mendalam, observasi dan telaah dokumen. Data dianalisis dengan teknik analisis kualitatif. Untuk menjaga validitas data dilakukan dengan metode triangulasi. Informasi yang diperlukan adalah informasi tentang alur proses penyusunan perencanaan, konsultasi, bimbingan teknis dan koordinasi.

\section{HASIL}

\section{Alur Perencanaan}

Sebagian dari informan ada mengikuti alur perencanaan tahunan, seperti ungkapan informan berikut ini:

"Yang jadi langkah pertama kita adalah mengkaji renstra. Apa saja yang menjadi target dalam renstra itulah yang akan direncanakan program dan kegiatannya. Usulan program dan kegiatan dari tiaptiap bidang nantinya akan kita analisis. Dalam menganalisis situasi kita melakukannya dengan pohon masalah, mana masalah yang paling besar dampaknya ke kematian itulah nantinya yang akan dijadikan prioritas program dan kegiatan. Tujuan serta sasaran ditetapkan setelah kita menetapkan program-program prioritas kita. Setelah kita tahu program maupun kegiatan yang akan dilakukan selanjutnya direncanakan anggarannya (RKA). Dari RKA sampai nanti jadi DPA. Selain itu kita juga menyinkronkan kegiatan dengan propinsi. Sehingga kita dapat memanfaatkan dana dekonsentrasi" (Informan 3)

Akan tetapi ada juga yang tidak mengikuti alur perencanaan seperti ungkapan Informan berikut ini:

"Kegiatan pertama kami melihat data/laporan. Contohnya, kegiatan penanggulangan trauma psikososial pasca gempa. Gangguan ini sudah masuk dalam sepuluh penyakit terbanyak, makanya dari situ kami bertolak menyusun perencanaan. Atau apa permasalahan yang menonjol di puskesmas maka dari situ kita mengangkatnya untuk perencanaan kedepan" (Informan 10)

Di tingkat UPT juga melaksanakan alur perencanaan yang berbeda, seperti yang disampaikan oleh informan berikut ini:

"GFK merencanakan obat berdasarkan pola konsumsi. Berapa obat yang terpakai tahun lalu, itu yang akan direncanakan tahun berikutnya. Perencanaan dimulai dari berapa pagu yang 
dianggarkan untuk GFK, kalau sudah jelas dananya baru disusun berapa kebutuhan obat. Biasanya dilihat dulu obat bantuan dari pusat/propinsi. Apa yang kurang atau tidak ada baru direncanakan" (Informan 13).

"Kita biasanya melihat permasalahan dari berapa sasaran kita, dan kita lihat capaian tahun lalu. Apakah rendah atau mencapai target, kalau rendah berarti harus ditingkatkan lagi, maka untuk tahun sekarang biasanya kegiatan ini kita rencanakan lagi. Atau analisa tahun lalu dulu, lalu dilihat sasaran tahun sekarang, seperti itu kita menentukan permasalahan. Kalau untuk menentukan prioritas masalah \biasanya kita melihat perkembangan tahun lalu dan bagaimana tahun sekarang, kalau memang masih jauh capaiannya maka diprioritaskan lagi" (Informan 14).

"Kita lihat dulu apa permasalahan yang ada, kemudian baru kita lihat dari semua masalah yang ada mana yang paling prioritas. Cara menentukan prioritas disini masih ngambang, kalau kita merasa masalah itu perlu maka kita prioritaskan"( Informan $15)$.

Dari hasil wawancara mendalam dapat disimpulkan bahwa tenaga perencana menggunakan alur perencanaan yang masih berbeda akan tetapi dalam menentukan program/kegiatan selalu berangkat dari masalah yang menjadi prioritas. Dari telaah dokumen dalam penyusunan perencanaan tidak ada panduan tertulis yang jadi pedoman tenaga perencana dalam menyusun perencanaan dan perencanaan yang diusulkan ada dibahas secara bersama-sama yang dapat dilihat dari notulen rapat.

\section{Konsultasi}

Pelaksanaan konsultasi sangat perlu dilakukan guna memperoleh masukan dan informasi tentang penyusunan perencanaan tahunan ke tingkat yang lebih tinggi. Sehubungan dengan penyusunan perencanaan tahunan Dinas Kesehatan Kabupaten Padang Pariaman melakukan konsultasi ke Pemerintah Daerah (Pemda) Kabupaten Padang Pariaman, seperti disampaikan informan berikut:

"Konsultasi dalam menyusun perencanaan ada dilakukan terutama ke Pemda/Bappeda. Biasanya yang terlibat dalam kegiatan konsultasi itu Kadiskes, Sekretaris maupun Subbag Perencanaan. Dalam melakukan konsultasi ataupun mengikuti rapat-rapat di Bappeda, kemampuan melobi sangat penting agar apa yang kita usulkan dapat dimasukkan dalam anggaran dana APBD"( Informan 2)

Informasi yang didapat dari Bappeda menyatakan bahwa Dinas Kesehatan Kabupaten Padang Pariaman ada melakukan konsultasi, seperti yang disampaikan informan berikut ini:

"Konsul yang dilakukan oleh Dinkes ada, biasanya kalau mau mengajukan program selalu berkonsultasi.
Kalau tidak, apabila kita ragu kita yang memanggil mereka"( Informan 16).

Sedangkan konsultasi ke Propinsi terkait dengan penyusunan perencanaan sejak otonomi daerah ini tidak lagi dilakukan. Untuk menyinkronkan program dan kegiatan dengan propinsi biasanya propinsi yang melakukan sosialisasi ke Dinas Kesehatan Kabupaten/Kota atau mengundang para pemegang program ke Dinas Kesehatan Propinsi Sumatera Barat. Kegiatan menyinkronkan program dan kegiatan ini oleh sebagian informan dianggap sebagai kegiatan konsultasi dalam penyusunan perencanaan, seperti yang disampaikan informan berikut ini:

"Kalau konsultasi ke propinsi dalam perencanaan kita tidak melakukan, karena semenjak otonomi ini kita langsung konsultasi ke Pemda/Bappeda. Untuk menyinkronkan kegiatan dengan propinsi biasanya pemegang program dinkes kabupaten diundang langsung oleh pemegang program di dinkes propinsi. Sehingga dari situ orang-orang pemegang program di dinkes kabupaten mengetahui program-program propinsi. Apabila ada program yang didanai dari dana dekonsentrasi biasanya tidak dianggarkan lagi untuk usulan dalam APBD II" (Informan 2).

Konsultasi tentang penyusunan perencanaan untuk tingkat bidang, seksi maupun UPT, selain diundang ke Propinsi atau menanyakan langsung program-program Propinsi juga melakukan konsultasi langsung ke Kepala Dinas, seperti disampaikan informan berikut:

"Konsultasi ke propinsi tidak ada dilakukan tetapi dalam menyusun perencanaan konsultasi dilakukan ke Kepala Dinas" (Informan 10).

Informan dari salah satu puskesmas menyatakan dalam menyusun perencanaan tidak ada melakukan konsultasi, tetapi dokumen perencanaan yang telah disusun dimasukkan langsung ke Dinas Kesehatan Kabupaten Padang Pariaman, seperti disampaikan informan berikut:

"Konsul biasanya tidak ada, yang penting dibuat saja perencanaan itu dan dimasukkan ke dinkes" (informan 15)

Permasalahan terkait konsultasi ini disampaikan oleh informan berikut ini:

"Permasalahnnya kadang para pemegang program langsung saja konsultasi ke propinsi dan melakukan kegiatan yang didanai propinsi kadang tidak melaporkan dulu ke tingkat Dinkes Kabupaten Padang Pariaman berapa anggaran dananya, tetapi hal tersebut tidak terlalu masalah karena setelah kegiatan selesai biasanya kegiatan selalu di laporkan" (informan 2).

Dari hasil wawancara mendalam di Dinas Kesehatan Kabupaten Padang Pariaman terkait konsultasi dapat disimpulkan bahwa pelaksanaan 
konsultasi sehubungan dengan perencanaan dilakukan ke Bappeda yang mewakili Pemda. Untuk menyinkronkan program dan kegiatan dengan propinsi agar nantinya bisa memanfaatkan dana dekonsentrasi propinsi biasanya konsultasi langsung dilakukan oleh para pemegang program, sehingga dalam menyusun perencanaan nantinya para pemegang program sudah mengetahui program dan kegiatan yang didanai propinsi dan tidak menganggarkan lagi program dan kegiatan tersebut dalam anggaran APBD. Tetapi dalam pelaksanaan konsultasi ke propinsi kontrol/monitoring dari pimpinan masih kurang sehingga dalam perencanaan program-program yang didanai propinsi tidak terangkum dalam dokumen perencanaan karena masing-masing program melaksanakannya sendiri.

\section{Bimbingan Teknis}

Dalam penyusunan perencanaan sangat dibutuhkan bimbingan teknis, tetapi bimbingan teknis dalam penyusunan perencanaan program maupun kegiatan yang dilakukan oleh Dinas Kesehatan Propinsi Sumatera Barat tidak ada, bimbingan teknis yang dilakukan oleh Dinas Kesehatan Propinsi Sumatera Barat baru sebatas bimbingan teknis terkait pelaksanaan program, seperti yang disampaikan informan berikut ini:

"Bimtek sehubungan dengan program ada dari propinsi, tetapi bimtek terkait perencanaan itu belum ada" (informan 4).

Bimbingan teknis terkait penyusunan perencanaan sejak otonomi ini dilakukan oleh Bappeda. Untuk tahun 2010, Dinas Kesehatan Kabupaten Padang Pariaman mendapat bimbingan teknis dari Bappeda Kabupaten Padang Pariaman, seperti yang disampaikan oleh informan dari Dinas Kesehatan Kabupaten Padang Pariaman dan Bappeda Kabupaten Padang Pariaman, sebagai berikut:

"Kalau bimtek dari propinsi sendiri dalam menyusun perencanaan itu tidak ada, yang ada itu dari Bappeda" (informan 2).

"Bimtek ada dilakukan, kalau ada perubahan sistem kita melakukan bimtek. Awal tahun kita juga memberikan pengarahan kepada mereka untuk membuat RKT. Bimtek yang kita lakukan terkait perencanaan seperti kemana arah program, arah kebijakan" (informan 16).

Dari hasil wawancara mendalam di Dinas Kesehatan Kabupaten Padang Pariaman dapat disimpulkan bahwa bimbingan teknis dalam hal penyusunan perencanaan tidak ada dilakukan oleh Dinas Kesehatan Propinsi karena di era otonomi ini masalah perencanaan merupakan kewenangan dari Pemda dan bimbingan teknis terkait perencanaan biasanya dilakukan langsung oleh Bappeda. Bimbingan teknis yang diberikan menurut informan dari Bappeda adalah apabila ada kebijakan baru atau adanya perubahan dalam sistem perencanaan maka dilakukan bimbingan teknis dan arahan terkait dengan perencanaan. Sedangkan bimbingan teknis yang dilakukan oleh Dinas Kesehatan Propinsi Sumatera Barat adalah terkait dengan pelaksanaan kegiatan di masing-masing program.

\section{Koordinasi}

Koordinasi lintas program maupun lintas sektor di Dinas Kesehatan Kabupaten Padang Pariaman sudah dilakukan tetapi masih dirasakan kurang oleh sebagian informan, seperti yang disampaikan informan berikut ini:

"Koordinasi ini dalam pelaksanaan masih setengah hati. Untuk lintas program maupun lintas sektor. Saat perencanaan ada kesepakatan tetapi setelah pelaksanaan sendiri-sendiri" (informan 1).

"Untuk lintas program koordinasi dalam penyusunan perencanaan agak kurang, seharusnya mereka saling berkoordinasi sehingga diharapkan nantinya tidak banyak kegiatan yang diusulkan. Kalau dapat satu kegiatan untuk mencapai beberapa indikator, bukan satu kegiatan satu indikator yang ingin dicapai. Kalau lintas sektor seperti program KB, kita koordinasinya dengan $B K K B N$, atau untuk mengatasi rabies kita ada juga koordinasi dengan dinas peternakan'"(informan 12).

"Koordinasi agak kurang disini, koordinasi lintas program ada tapi kurang optimal. Koordinasi lintas sektor ada biasanya dengan kecamatan maupun nagari. Kembali kepada mau tidak lintas sektor itu mau bekerja sama. Kadang ada juga lintas sektor yang tidak mau tahu jadinya program kita susah terlaksananya"(informan 14).

Saran yang disampaikan oleh informan terkait dengan koordinasi ini adalah sebagai berikut:

"Sarannya kalau dapat semua lintas terkait maunya memberikan pemahaman khusus terhadap permasalahan yang ada sehingga bisa dijalankan sesuai yang direncanakan" (informan 1).

Dari hasil wawancara mendalam terkait koordinasi lintas program di Dinas Kesehatan Kabupaten Padang Pariaman masih belum optimal pelaksanaannya karena dalam menentukan kegiatan belum dibahas secara bersama-sama, sehingga nantinya dari masing-masing bidang menghasilkan usulan kegiatan yang banyak, padahal indikator yang ingin dicapai sama.

\section{PEMBAHASAN}

Dalam penyusunan perencanaan di Dinas Kesehatan Kabupaten Padang Pariaman ditemukan tenaga perencana belum memakai alur perencanan yang sama akan tetapi dalam menetapkan program/kegiatan semua sudah berdasarkan pada 
prioritas masalah. Langkah-langkah perencanaan yang digunakan oleh masing-masing tenaga perencana atau masing-masing seksi masih berdasarkan pengetahuan dan mengadopsi dari cara-cara penentuan prioritas dari bidang masing-masing. Ada yang memulai perencaaan dari meriview renstra serta melakukan analisis masalah berdasarkan masalah yang berdampak kepada peningkatan angka kematian maka itu yang dijadikan prioritas dalam perencanaan nantinya, ada juga dengan melihat target program yang tak tercapai tahun lalu direncanakan lagi serta ada juga dengan memulai dari menganalisa data sepuluh penyakit terbanyak. Hal ini disebabkan karena belum ada panduan ataupun pedoman yang jadi acuan tiap seksi dalam menyusun perencanaan.

Untuk perencanaan tahunan, alur perencanaan dimulai dari review renstra SKPD, analisis kondisi dan masalah sektor SKPD, perumusan tujuan dan sasaran tahun rencana, perumusan program dan kegiatan SKPD tahun rencana dan dalam perumusan program dan kegiatan perlu memperhatikan standar pelayanan minimal, serta identifikasi program kegiatan pusat dan propinsi, sampai nantinya disusun rancangan akhir renja SKPD (LGSP, 2007).

Dalam menyusun perencanaan kesehatan perlu memperhatikan alur proses penyusunannya dan setiap tenaga perencana diberikan panduan penyusunan rencana, sehingga nantinya dapat dihasilkan sebuah perencanaan yang bermutu dan sesuai dengan aturan yang ada.

Selain memperhatikan alur perencanaan yang terpadu, maka konsultasi sangat diperlukan juga bagi kelancaran proses perencanaan terutama konsultasi ke pimpinan dan juga ke Pemerintah Daerah yang diwakili oleh Bappeda. Konsultasi berguna dalam memahami maupun memperjelas program/kegiatan yang diusulkan.

Di Dinas Kesehatan Kabupaten Padang Pariaman ditemukan bahwa pelaksanaan konsultasi sehubungan dengan perencanaan dilakukan ke Bappeda yang diwakili oleh Kepala Dinas, Sekretaris Dinas maupun Sub Bagian Perencanaan. Hal yang dikonsultasikan lebih kepada berapa anggaran dana yang dialokasikan untuk semua kegiatan yang diusulkan. Dalam konsultasi, kemampuan melobi dari tenaga perencana yang datang ke Bappeda sangat menentukan besaran anggaran dana yang akan dialokasikan untuk seluruh kegiatan. Apabila bisa meyakinkan pihak Bappeda akan pentingnya kegiatan tersebut dilakukan maka kemugkinan kegiatan yang diusulkan tidak akan dihapus dari usulan rencana.

Untuk menyinkronkan program dan kegiatan dengan propinsi agar nantinya bisa memanfaatkan dana dekonsentrasi propinsi biasanya konsultasi langsung dilakukan oleh para pemegang program, sehingga dalam menyusun perencanaan nantinya para pemegang program sudah mengetahui program dan kegiatan yang didanai propinsi dan tidak menganggarkan lagi program dan kegiatan tersebut dalam anggaran APBD. Tetapi dalam pelaksanaannya, monitoring terhadap pelaksanaan konsultasi masih kurang maksimal, sehingga berakibat pada kurang terakomodirnya usulan rencana dari propinsi dalam Renja Dinas Kesehatan Kabupaten Padang Pariaman. Padahal program-program yang didanai oleh propinsi juga mempunyai potensi yang cukup besar dalam pencapaian target indikator kesehatan di Kabupaten Padang Pariaman.

Menurut Ernawati (2004) pelaksanaan konsultasi sangat diperlukan untuk proses penyusunan perencanaan dan penganggaran kesehatan pada era otonomi ini karena masih banyak keterbatasanketerbatasan yang ada di daerah, konsultasi diperlukan guna memperoleh informasi mengenai perencanaan dan penganggaran terutama dari propinsi dan pusat, dalam hal ini Dinas Kesehatan Propinsi dan Departemen Kesehatan, yang frekuensinya belum optimal, hal ini dikarenakan dana yang sangat terbatas.

Pelaksanaan konsultasi saat ini bukan sesuatu hal yang sulit lagi karena sekarang berbagai sarana banyak tersedia. Untuk menghemat waktu, biaya serta tenaga konsultasi dapat dilakukan melalui telepon, sarana informatika (e-mail) dan sebagainya. Dalam pelaksanaan konsultasi tetap harus dimonitoring oleh pimpinan sehingga rencana yang ada di Dinas Kesehatan Propinsi bisa terakomodir juga dalam Renja di Dinas Kesehatan Kabupaten.

Untuk menghasilkan perencanaan yang bermutu, perlu dilakukan bimbingan teknis bagi tenaga perencana. Bimbingan teknis dalam hal penyusunan perencanaan tidak ada dilakukan oleh Dinas Kesehatan Propinsi karena di era otonomi ini masalah perencanaan merupakan kewenangan dari Pemda dan bimbingan teknis terkait perencanaan biasanya dilakukan langsung oleh Bappeda. Bimbingan teknis yang diberikan menurut informan dari Bappeda adalah apabila ada kebijakan baru atau adanya perubahan dalam sistem perencanaan maka dilakukan bimbingan teknis dan arahan terkait dengan perencanaan. Sedangkan bimbingan teknis yang dilakukan oleh Dinas Kesehatan Propinsi Sumatera Barat adalah terkait dengan pelaksanaan kegiatan di masing-masing program.

Bimbingan teknis dari pusat/propinsi masih diperlukan terutama guna memberika arahan terhadap cara pencapaian program ataupun mengkomfirmasikan program-program yang inovatif sehingga daerah bisa melaksanakan dengan baik..

Koordinasi lintas program dan sektor sangat perlu dilakukan guna menyinkronkan kegiatan dari masing-masing bidang. Di Dinas Kesehatan Kabupaten Padang Pariaman masih belum maksimal pelaksanaannya. Dalam rapat penyusunan perencanaan sepakat dalam melaksanakan kegiatan untuk mencapai 
indikator yang sama, akan tetapi setelah pelaksanaan masing-masing bidang banyak yang melaksanakan sendiri-sendiri kegiatannya. Koordinasi lintas sektor juga belum maksimal pelaksanaannya walaupun ada beberapa kegiatan yang dilakukan bersama dengan sektor lain, seperti kerjasama dengan BKKBN dalam program KB dan pemberantasan rabies dengan Dinas Peternakan.

Koordinasi sangat ditentukan oleh kemampuan sumber daya manusia untuk melakukan persamaan persepsi, sehingga memperoleh keterpaduan dalam penyusunan perencanaan dan penganggaran kesehatan, yang sangat dipengaruhi oleh kemampuan untuk mempunyai share vision serta kemampuan untuk mempersiapkan data di masing-masing program (Ernawati, 2004).

Kurang maksimalnya pelaksanaan koordinasi disebabkan pemahaman yang kurang akan koordinasi. Makna koordinasi yang dilakukan selama ini hanya dalam konteks pelaksanaan kegiatan, padahal dalam merencanakan juga diharapkan ada koordinasi sehingga apabila ada kesamaan maksud dan tujuan yang ingin dicapai dapat direncanakan bersama sehingga dapat menghemat dari segi tenaga, biaya dan waktu.

Koordinasi lintas sektor harus lebih ditingkatkan lagi dan melakukan sosialisasi serta pertemuan-pertemuan secara rutin sehingga sektor lain akan memahami dan mengerti permasalahanpermasalahan kesehatan yang ada dan diperlukan pemahaman khusus terhadap permasalahan yang dihadapi sehingga nantinya bisa direncanakan dan dijalankan sesuai dengan yang disepakati bersama.

\section{KESIMPULAN}

Alur perencanaan di Dinas Kesehatan Kabupaten Padang Pariaman belum mengikuti alur ataupun langkah-langkah perencanaan terpadu. konsultasi dalam penyusunan perencanaan, bimbingan teknis dan koordinasi lintas program maupun sektor sudah berjalan tetapi dalam pelaksanaannya masih belum maksimal.

\section{SARAN}

1. Pedoman dalam proses penyusunan perencanaan harus dibagikan kepada seluruh tenaga yang terlibat dalam perencanaan.

2. Dalam melakukan konsultasi terkait penyusunan perencanaan perlu dimonitoring oleh pimpinan mulai proses penyusunan sampai pelaksanaan suatu kegiatan.

3. Mensosialisasikan setiap bimbingan teknis dari Bappeda kepada semua tenaga perencana terkait dengan hal-hal baru yang berkaitan dengan perencanaan.

4. Untuk lintas program disarankan tiap-tiap pemegang program saling berkoordinasi dalam pelaksanaan kegiatan untuk mencapai indikator yang sama sehingga dapat menghemat waktu, tenaga dan biaya. Bagi lintas sektor agar melakukan rapat koordinasi rutin tiap akhir tahun terkait dengan kesehatan sebelum memulai penyusunan perencanaan untuk menyinkronkan kegiatan dalam mengatasi permasalahan yang sama.

\section{DAFTAR PUSTAKA}

Bakri, Hamzah., 2001. Penguatan Sistem Perencanaan Kesehatan Kabupaten/Kota. Disampaikan pada Pelatihan Perencanaan dan Penganggaran Kesehatan Terpadu (P2KT) Kabupaten/Kota Se Sulawesi Selatan Tahun 2001. Makasar.

Bappenas. 2009. Pembangunan Kesehatan dan Gizi di Indonesia: Overview dan Arah Kedepan. Background Study RPJMN 2010-2014. Jakarta. [15 April 2010].

Ernawati, Ch. Tuty., 2004. Analisis Sistem Perencanaan dan Penganggaran Kesehatan di Dinas Kesehatan Kota Payakumbuh Provinsi Sumatera Barat Tahun 2004. Tesis. Universitas Indonesia, Jakarta.

LGSP, 2007. Seri Perencanaan Partisipatif: Penyusunan Perencanaan Pembangunan Daerah Bagi Eksekutif, Legislatif dan Organisasi Masyarakat Sipil (Bahan Pelatihan dan Pendampingan), Bagian 5: Rencana Kerja Satuan Kerja Perangkat Daerah. Jakarta.

Muninjaya, A.A. Gde., 2004. Manajemen Kesehatan. Edisi 2. EGC. Bandung.

Padang Pariaman, Dinkes., 2008. Rencana Strategis Dinas Kesehatan Kabupaten Padang Pariaman Tahun 2006-2010.

Padang Pariaman, Dinkes., 2010. LPPD Dinas Kesehatan Kabupaten Padang Pariaman Periode 2006 s/d 2010. 